\title{
Market-based places, diversity, and intersectional exclusion
}

\author{
Paulo Roberto Chaves Dalpian ${ }^{1}$ \\ TENIZA DA SILVEIRA ${ }^{2}$ \\ ${ }^{1}$ STAMFORD INTERNATIONAL UNIVERSITY, BANGKOK, THAILAND \\ 2 Universidade federal do Rio Grande do Sul (UFRGS) / Escola de AdMinistração, Porto Alegre - RS, Brazil
}

\begin{abstract}
This article aims to understand how the incidence of intersectionality operates within market-based places that present themselves as diverse or open to diversity. The study adopted the intersectional approach to locate minorities (the gay male public) within a network of relationships within this context (gay market-based places). The study involved a two-year-long (2015 and 2016) fieldwork conducted in two cities: Porto Alegre and Montreal, comprising 26 interviews. The findings show how the exclusion of marginalized categories occurs even within places that ostensibly cater to a public formed by such categories. Finally, the article discusses the managerial implication of how the expectation of open to diversity is counterintuitive, since the more broadened the offer in a market-based place, the bigger the perception of intersectional exclusion.
\end{abstract}

Keywords: Intersectionality. Place. Exclusion. Gay.

\section{Locais de mercado, diversidade e exclusão interseccional}

\section{Resumo}

Este artigo busca entender como a incidência da interseccionalidade opera dentro de locais de mercado que se apresentam como diversos ou abertos à diversidade - especificamente, lugares gays. Utiliza-se a abordagem interseccional para localizar posições minoritárias (o público gay masculino) em uma malha de relações que se estabelece em tais contextos (locais de mercado categorizados como gays). 0 artigo apresenta os resultados de um trabalho de campo conduzido por 2 anos (2015 e 2016) em 2 metrópoles, Porto Alegre e Montreal (Canadá), com base em entrevistas realizadas com 26 indivíduos. Os achados de pesquisa indicam o modo como a exclusão continua operando em categorias marginalizadas, mesmo dentro de lugares que ostensivamente recebem membros de categorias que já sofrem preconceito. Por fim, discute-se a implicação gerencial de como a expectativa de abertura à diversidade é contraintuitiva, já que quanto mais ampliada a oferta no local de mercado aberto à diversidade, maior a percepção de exclusão interseccional.

Palavras-chave: Interseccionalidade. Lugar. Exclusão. Gay.

\section{Lugares de mercado, diversidad y exclusión interseccional}

\section{Resumen}

Este artículo busca entender cómo la incidencia de la interseccionalidad opera dentro de lugares de mercado que se presentan como diversos o abiertos a la diversidad-específicamente, lugares gays. Utilizamos el enfoque interseccional para ubicar posiciones minoritarias (el público gay masculino) en una malla de relaciones que se establecen dentro de tales contextos (lugares de mercado categorizados como gays). Ofrecemos los resultados de un trabajo de campo conducido por dos años (2015 y 2016) en dos metrópolis: Porto Alegre y Montreal (Canadá) con base en entrevistas realizadas a 26 individuos. Nuestros hallazgos indican cómo la exclusión continúa operando en categorías marginadas incluso dentro de lugares que ostensivamente reciben miembros de categorías que ya sufren prejuicio. Finalmente, discutimos la implicación gerencial de cómo la expectativa de apertura a la diversidad es contraintuitiva, ya que cuanto más ampliada es la oferta en el lugar de mercado abierto a la diversidad, mayor es la percepción de exclusión interseccional.

Palabras clave: Interseccionalidad. Lugar. Exclusión. Gay. 


\section{INTRODUCTION}

Studies involving places and consumption analyze how exclusion based on difference takes place within marketplaces (GOPALDAS and DEROY, 2015). The term 'marketplace discrimination' is used when the difference is grounded on association with groups (CROCKETT, GRIER and WILLIAMS, 2003), for example, when a person is associated with the group 'women,' the association implies that this person is not allowed into some places. The critical spatial theory analyzes differences that are reinforced by businesses that act as hegemonic entities (SAATCIOGLU and OZANNE, 2013). Such a critical approach analyzes the difference and exclusion in marketplaces that present vulnerable (consumers) and hegemonic (suppliers) actors (BAKER, GENTRY and RITTENBURG, 2005; COMMURI and EKICI, 2008). These spaces show asymmetric systems of power that create contexts of exclusion for vulnerable consumers. Therefore, the concept of difference in the critical spatial theory is observed in the relationship between hegemonic and vulnerable actors (SAATCIOGLU and CORUS, 2016).

However, the concept of difference can be analyzed in broader approaches to exclusion. Apart from the exclusion of vulnerable people by hegemonic actors (SAATCILOGLU and CORUS, 2016), the difference can also be treated in other ways between and within disciplines: the form of treatment can be one-dimensional or multidimensional (GOPALDAS and DEROY, 2015). The one-dimensional treatment, which is becoming rare (especially regarding sexual diversity), takes into account an isolated characteristic of a discriminated group. Such an isolated characteristic can be income (LANGLEY, 2014), gender (THOMPSON and HAYTKO, 1997), sexuality (KATES, 2000; 2002), race and ethnicity (JAFARI and GOULDING, 2008), feminine bodies (GURRIERI, PREVITE and BRACE-GOVAN, 2013), or look (SANGHVI and HODGES, 2015).

In multidimensional approaches, theory usually combines more than one characteristic. For example, income and gender (AGIER and SZAFARZ, 2013; DENISSEN and SAGUY, 2014; HUTTON, 2015), age, gender, and sexuality (OLIVER and HYDE, 1993; BORGES and SCHOR, 2005; LINDAU, SCHUMM, LAUMANN et al., 2007), race and gender (CROCKETT, GRIER and WILLIAMS, 2003; ACKER, 2006; CARR, SZYMANSKI, TAHA et al., 2014); or class, ethnicity, and gender (CROCKETT and WALLENDORF, 1998; LISBON, 2003; ROSEMBERG and ANDRADE, 2008).

One of the multidimensional research paradigms is intersectionality (CRENSHAW, 1989; COLLINS, 1990). According to Gopaldas $(2013$, p. 90) "intersectionality' refers to the interactivity of social identity structures such as race, class, and gender in fostering life experiences, especially experiences of privilege and oppression." This approach stems from the observation that race and gender affect black women simultaneously (CRENSHAW, 1989).

Therefore, this article uses the concept of intersectionality to understand, contextually, how exclusion is established within marketplaces that are considered open to diversity. More specifically, the study explores the phenomenon of the incidence of intersectionality in exclusion within the context of the minority group gay men. Such category was chosen because there is a need for categorical boundaries to build specific analysis. We recognize, however, that several categories cut across the field studied here. Such categories are unified under the acronym LGBT (lesbian, gay, bisexual, crossdresser, transsexual or transgender). In this sense, this study contributes to the proposition by Gopaldas (2013), advocating the need for more research on diversity in marketing and consumption.

While studies involving structural dynamics (DELOZIER e RODRIGUE, 1996; KATES, 2000, 2002; BETTANY, DOBSCHA and O'MALLEY, 2010) seek to understand how exclusion occurs between the majority (society) and minority (gays); this study seeks, through intersectionality lenses (CRENSHAW, 1989; COLLINS, 1990), to show how exclusion works internally in the minority groups. Therefore, we link the categories of consumers and producers (bars, restaurants, saunas) considered as gay.

The research question is:

- How does intersectional incidence operate within marketplaces considered to be gay?

In order to understand such exclusion, our field research is connected with sexuality, intersected with race, age, and income. The research sites are gay places, identified by informants in discovery-oriented field research. The places include bars, clubs, saunas, restaurants, neighborhoods, villages and other commercial places in the geography of gay places. The data are part of a 2-year survey (2015 and 2016) conducted in Brazil and Canada. 


\section{LITERATURE REVIEW}

Research works evolving human sexuality began to be conducted in the early nineteenth century. However, most of the early studies were based on the medical and clinical field (LEZNOFF, 1954). Slowly, especially in the 1970s and 1980s, the fields of sociology and geography begin to conceptualize the terms "gay space," "gay ghetto," and "gay places" (PODMORE, 2006). The study of places and commercial spaces also began to flourish in the field of geography beginning in the 1990s (PODMORE, 2006). In marketing, studies on gay as a cultural category were neglected before the 1990s and increased after that and during the 2000s (KATES, 2000). For example, the Journal of Homosexuality launched a special edition in 1996 entitled "Gays, Lesbians, and Consumer Behavior." However, our research question does not imply analyzing how two groups (e.g., "gays and society") are related in the consumer-focused network of relationships - but rather how intragroup relationships are established in exclusionary behavior.

The analysis is based on the intersectionality approach, where each individual is placed in a single position marked by two or more identity categories, which operate simultaneously (CRENSHAW, 1989, 1991; GOPALDAS and SIEBERT, 2018). Therefore, processes of exclusion rarely operate in only one form. Intersectionality shifts the experience of exclusion to the internal mediation of minority groups. For Crenshaw (1991, p. 1296), intersectionality (as opposed to structural analysis) may be more broadly useful as a "[...] way of mediating the tension between assertions of multiple identity and the ongoing necessity of group politics."

Therefore, intersectionality emphasizes the analysis of internal exclusion in minority groups. Studies using intersectionality enable researchers to consider multiple power systems and structures that shape identities. The use of intersectionality results in a multidimensional approach that is more inclusive in its conclusions, than a one-dimensional approach. Also, the multidimensional approach is considered the only one that recognizes the heterogeneity of representations for identity categories. In other words, it is the only approach that addresses the inclusion of multidimensional categories of exclusion (race, gender, ethnicity, age) (GOPALDAS and DEROY, 2015). Such categories tend to be neglected by one-dimensional social movements (for example, the one-dimensional feminism that, according to Collins (1990), excludes black women), and by one-dimensional research designs.

\section{Marketplace and exclusion}

Taking into consideration the recommendation of Gopaldas and DeRoy (2015) regarding the multidimensional research design, this work on structural and unidimensional exclusion in marketplaces analyzes how consumers are restricted in their access to the retailer or service provider, i.e., institutionalized exclusion. Whether by the state or by businesses, such institutional exclusion creates vulnerability in marketplaces transactions (WANG and TIAN, 2013; KHARE and VARMAN, 2016). Such vulnerability arises from barriers formed by actors in structural power positions.

The analysis of institutional exclusion points to power asymmetry among producers and consumers. According to Nakamura (2010) and Walker, Keane, and Burke (2010), observing the exclusion approach adopted by producers, two forms of consumers' exclusion are expected. One that is caused by the producers (applying high fixed costs to provide goods and services) and the other caused by the consumers (with insufficient resources or information). However, both forms of consumer exclusion, according to Gopaldas and Siebert (2018), are outcomes of the broad control applied by the supply apparatus: the authors consider such control as an operation "fueled by the legacies of history, aspirational marketing logic, and an industry-wide distribution of discriminatory work" (GOPALDAS and SIEBERT, 2018, p. 4). As well as recognizing these forms of exclusion, this work adds the exclusion from the perspective of the intersectionality, i.e., even consumers with sufficient resources and information may be prevented from consuming a product or service.

Therefore, this article approaches the consumer perspective regarding the offers in their contexts - gay places. We questioned how the places studied participate in the formulation of the subjectivities of gay consumers. In servicescape, for example, several relationships involve brands themselves as gatekeepers, models and class brokers (DION and BORRAZ, 2017). If one thinks of a luxury brand, such a brand can act as a broker of what it is "to be luxurious." The theoretical model indicates that there will be a sign of what is acceptable behavior for consumers. However, the model fails to capture what occurs when consumers are prevented from participating in such a subjective formulation. For example, how a person who is part of an identity category (luxury, young, masculine) may be prevented from participating in the formulation of what is acceptable 
behavior for that category because they are, simultaneously, in another one (CRENSHAW, 1989; COLLINS, 1990; KHARE and VARMAN, 2016). This is a crucial issue that drives this study.

The restriction to participate (exclusion) was analyzed for gay places, i.e., the analysis based on producers or suppliers. The exclusion based on the producer is at the core of the concept of 'central-places' (NAKAMURA, 2010; WALKER, KEANE, and BURKE, 2010). Central-places are spaces of supply concentration, usually decided by the producers, without concern for the customers.

When positioning consumers in a multidimensional approach, the intention is to establish a concept on how they are positioned regarding the constraints in intra-group participation (consumers and gay market places). Rather than questioning the difference between the categories, we questioned the differences within the categories. This repositioning helps to understand how consumers may find themselves restricted in their marketplace. This is in line with the discussions put forward by Castilhos and Dolbec (2017): on the one hand, we respond to the call for more research on practices of exclusion in market spaces. On the other, we question the theoretical position of the authors, who argue that exclusion can be reduced to free-market logic, which depends only on the cultural and economic capital of consumers.

\section{METHOD}

A multi sited ethnography (MARCUS, 1995; KJELDGAARD, CSABA and GER, 2006) was carried out in two cities: Porto Alegre and Montreal. The fieldwork was carried out in these two cities to a) find contextual differences in fields that - although diverse - share some relationally built intersections, and $b$ ) add more intersections in the data, such as transnational identities. We also selected the two cities because they have different organizations and public policies regarding market spaces: while Montreal has a collection of gay market places clearly defined (Gay Village), Porto Alegre has more diffuse and spread out gay places in its urban geography (as shown in Figure 1).

Data collection was carried out through field work, mapping gay places in both cities. After gathering the first data, the urban environment was freely explored, with attention to gay social markers (gay couples at tables, holding hands on the street, LGBT flags, and others).

After this mapping, each commercial establishment on both sides of the street was visited in Montreal for the length of one block. In Porto Alegre, because the area targeted was dispersed, priority was given to establishments in the district known as the "gay district." Finally, using a procedure similar to the snowball procedure, the information gathering was expanded by: a) talking to customers in the places; and (b) collecting physical materials that lead from one place to another (in this case, pamphlets, magazines, gay guides, posters, etc.). The focus on gay men in this work stems from the need to create conceptual and empirical boundaries of sexuality, naturally, that such places and urban spaces are often interspersed with other LGBTQ + positions and experiences.

Although Figure 1 'freezes' the mapping process, it is worth remembering that this kind of process is always iterative, with changes and new findings that require constant remapping. 
Figure 1

Comparison of contexts: Porto Alegre and Montreal (2015-2016)

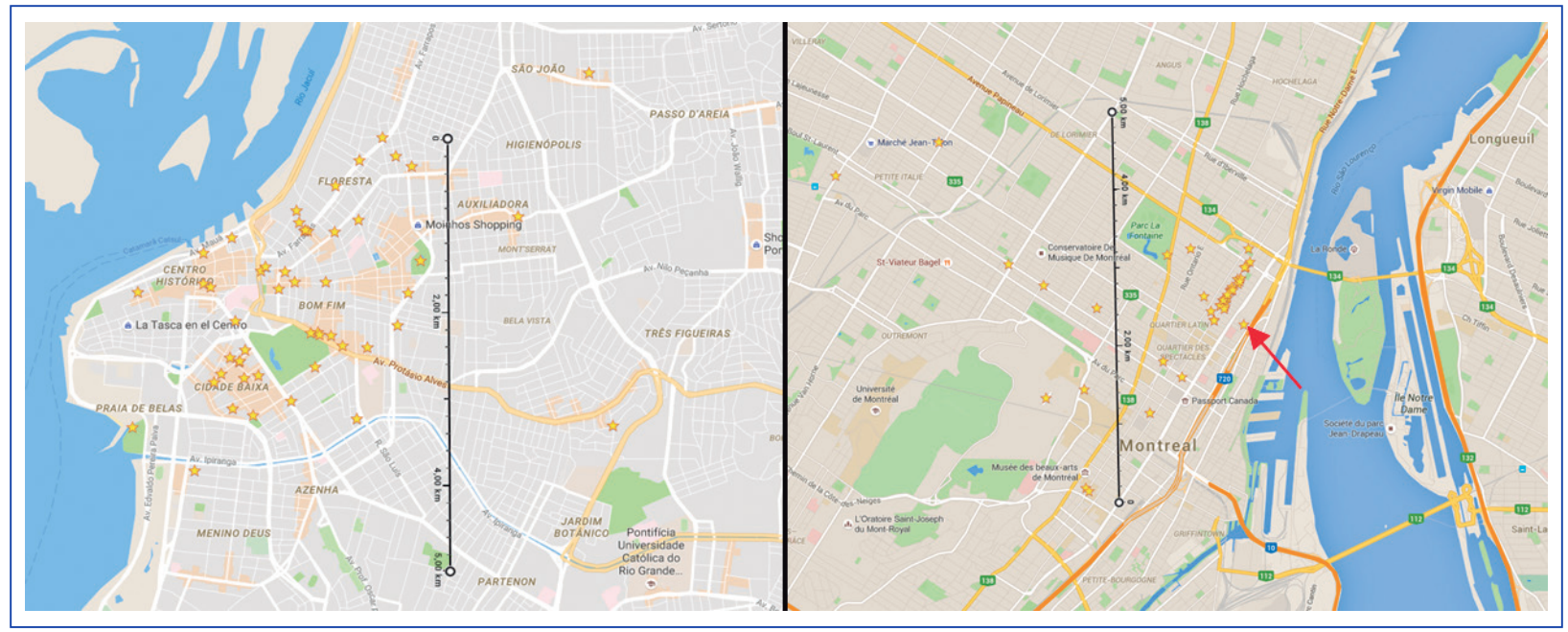

Source: Elaborated by the authors.

Different techniques of data collection were employed. The 26 interviews were conducted using the long interview technique (MCCRACKEN, 1988) and totaled about 29 hours of audio, transcribed in a total of 339 pages of text (single spaced). The interviews were conducted in Portuguese in Brazil and English in Canada. Subsequently, a roundtable was organized during the week PerversCité, on August 13, 2016, in partnership with another researcher, focused on critical spatial theory. The roundtable lasted 2 hours, and it was recorded and transcribed and counted on 12 participants from various nationalities (all Canadian residents) identified as LGBT. The roundtable discussed building LGBT spaces outside the nightlife context, with more opportunities for socializing and community building (less focused on alcohol consumption and parties). The places suggested during the roundtable helped to map out nonprofit organizations that could have escaped the primary method of collection. In total, observations were conducted in 43 places -22 in Montreal and 21 in Porto Alegre (only non-domestic places were counted and categorized, such as bars, cinemas, nightclubs, saunas, video stores, nonprofit organizations, restaurants, and strip clubs). The observations were conducted by the lead author, in the role of participant observer. The contact with staff and workers were restricted to the presentation and explanation of the visit of the lead author. The primary objective of the observations was to assemble and map the dispersion and urban distribution of gay places (see Figure 1). As a secondary objective, the visitation enabled the recruitment of participants. Finally, the complementary objective was to observe the structural details of accessibility and physical environment (such as lighting, noise, the motivation for customers' consumption, decoration). The average time spent in each place visited was 40 minutes. Field notes were recorded throughout the phase of data collection. Table 1 shows the profile of the interviewees, who responded individually. Information that would allow identifying the interviewees was changed, without jeopardizing data interpretation and analysis. 
Table 1

Interviewees' Profile

\begin{tabular}{|c|c|c|c|c|c|c|c|}
\hline \multirow[b]{2}{*}{ Name } & \multirow[b]{2}{*}{ City } & \multicolumn{6}{|c|}{ Intersections } \\
\hline & & Sexuality & $\begin{array}{c}\text { Age } \\
\text { (aprox.) }\end{array}$ & Income & Sero-logy & $\begin{array}{c}\text { Race } \\
\text { (Self-Declared) }\end{array}$ & Gender \\
\hline Carlos & Porto Alegre & Gay/DIS & 40 & Low & ? & White & Cis/Male \\
\hline Diego & Porto Alegre & Gay/DIS & 25 & Middle & $?$ & Pardo & Cis/Male \\
\hline Gil & Porto Alegre & Gay/DIS & 25 & Middle & - & Black & Cis/Male \\
\hline Lucas & Porto Alegre & Gay/DIS & 25 & Middle & ? & White & Cis/Male \\
\hline Marcia & Porto Alegre & Hetero & 60 & Middle & - & White & Trans/Female \\
\hline Otto & Porto Alegre & Gay/UND & 45 & High & ? & White & Cis/Male \\
\hline Pedro & Porto Alegre & Gay/UND & 30 & Middle & ? & Black & Cis/Male \\
\hline Rebecca & Porto Alegre & Hetero & 50 & High & - & Black & Trans/Female \\
\hline Renato & Porto Alegre & Gay/DIS & 25 & High & - & Pardo & Cis/Male \\
\hline Ricardo & Porto Alegre & Gay/DIS & 30 & High & - & White & Cis/Male \\
\hline Roberto & Porto Alegre & Gay/Partial & 30 & Low & - & Black & Cis/Male \\
\hline Aaron & Montreal & Gay/DIS & 35 & Middle & ? & Asian & Cis/Male \\
\hline Ahmed & Montreal & Gay/Partial & 30 & High & ? & Arab & Cis/Male \\
\hline Benjamin & Montreal & Gay/DIS & 80 & High & - & White & Cis/Male \\
\hline Brandon & Montreal & Gay/DIS & 60 & High + & + & Asian & Cis/Male \\
\hline Brice & Montreal & Gay/DIS & 55 & High & + & White & Cis/Male \\
\hline Derek & Montreal & Gay/DIS & 35 & Middle & - & Arab & Cis/Male \\
\hline Jacques & Montreal & Gay/DIS & 20 & Low & - & White & Cis/Male \\
\hline Kevin & Montreal & Gay/DIS & 50 & Low & ? & Black & Cis/Male \\
\hline Lewis & Montreal & Gay/Partial & 20 & Middle & - & White & Cis/Male \\
\hline Lilian & Montreal & Lesbian/DIS & 25 & Middle & - & White & Cis/Female \\
\hline Luke & Montreal & Gay/DIS & 70 & Middle & ? & White & Cis/Male \\
\hline Pierre & Montreal & Gay/DIS & 25 & Middle & - & White & Cis/Male \\
\hline Russel & Montreal & Gay/DIS & 60 & Middle & - & White & Cis/Male \\
\hline Saul & Montreal & Gay/Partial & 20 & Low & ? & Black & Cis/Male \\
\hline $\begin{array}{l}\text { Saturation } \\
\text { interview }\end{array}$ & Montreal & Gay/DIS & 25 & Middle & - & White & Cis/Male \\
\hline
\end{tabular}

Source: Elaborated by the authors.

UND = Undisclosed; DIS = Disclosed; Partial = Partially disclosed; Cis = Cisgender; Trans = Crossdresser, Transgender or Transsexual; Male $=$ male gender identity; Female $=$ Female gender identity .

\section{FINDINGS}

This section was organized by separating the observations and findings in each of the cities researched, and differentiating the consumers' relationship with the supply side in each case. Thus, the study describes a context for the cities, and then the results obtained during the field research are presented. After this presentation, we seek to answer the research question, organizing the discussion in subsections. 
When observing Figure 1, it is important to mention some differences in the geographical dispersion of places of consumption in both cities. In Montreal, there is a highly concentrated area of offers for gay consumers - which Nakamura (2010) calls the central-place system - whereas in Porto Alegre the offers are dispersed throughout the city.

\section{Intersectional exclusion in Montreal}

Montreal has an officially demarcated area for a Gay Village, sanctioned and approved by the municipal, provincial and national governments (HUNT and ZACHARIAS, 2008). This regulated offer, therefore, appears as an official tourist destination. The creation and delimitation of the Gay Village took place through a historical process. Before the creation, gay places were concentrated between Peel Street and Stanley Street in the commercial center of the city. However, the gay community suffered constant police repression in the 1970s (PODMORE, 2006). In the 1960s and 1970s, Montreal hosted two major events, the Expo 67 (an arts and entertainment fair), and the 1976 Olympics. In an attempt to clean the city center, establishments were forced to relocate in the current district (HUNT and ZACHARIAS, 2008) - which was a section on the same street, but away from the center and considered cheap and abandoned. Such reallocation was not accepted without conflict, and several protests occurred in the late 1970s and early 1980s (HUNT and ZACHARIAS, 2008).

\section{Exclusion as an attraction}

The specific delimitation generates a problem that Hunt and Zacharias (2008) call homonormativity. This term refers to a force driving offers and consumption possibilities to homogeneity and governing the practices and expressions that are acceptable within the officially sanctioned environment. In a way, the emergence of the gay district in Montreal created an attraction palatable to the heterosexual tourist. A space to observe gay consumers.

Aaron: Yeah, in the summer there are fireworks, but ... And you see a lot of - like - straight people passing through the Village and going home, going to ... uh ... passing through the Village, because it's a pedestrian road - they close the avenue [in the summer] - then it's kind of a zoo. I don't like it. Interviewer: What do you mean by "zoo"?

Aaron: [...] They think gays are weird - I mean, you know ...

Interviewer: Yes ...

Aaron: Or you see people having bachelor parties, and passing the Village as if it was "shameful," I dunno. [...] If someone takes you to the Village on your bachelor party, it's supposed to be shameful, right?

The above narrative demonstrates how state-sanctioned concentration has created a broader-than-expected offer - or a tourist destination (rather than amusement for gay audiences) - which entails unwanted entry by heterosexual tourists or consumers who consider their visit around the village in the same way as visiting "the zoo" (Aaron). The same homonormativity (HUNT and ZACHARIAS, 2008) implies in the 'normativity' of intersections.

Therefore, one of the ways intersectional exclusion is operated is the creation and expansion of benefits: by creating a Gay Village, the government controls and regulates acceptable and unacceptable behaviors. Also, it regulates the preferential consumer - tourists and people with income to participate and enjoy the attraction. The next subsection explores how producers segment intersections and how interviewees perceive intersections as restrictive.

\section{Exclusion through a palatable marketplace segmentation}

Saul's experience in the Village shows how the sanctioned and homonormative offer (HUNT and ZACHARIAS, 2008) excludes the intersections that visit the space and places and that are "near the bottom [of the pyramid]" (Saul). Likewise, Russel realizes a distance based on age, on the part of the bar staff in the Village. He supports this impression pointing out that the staff use, in French Quebec, the respectful treatment "vous" rather than "tu," with older people. However, specific places seek to better define their offer and restrict their market positioning. This practice implies in ease of consumption by some customers (NAKAMURA, 2010; CASTILHOS and DOLBEC, 2017), but restriction for others. 
Saul: No matter where I go - I've been to two cities in different provinces. I'll tell you: Toronto and Montreal. And ... I thought Montreal would be better, but it's the same shit. Because people ... There's a shitty hierarchy when you go to Village, and I'm near the bottom [of it].

Interviewer: Why do you feel near the bottom?

Saul: Because you're at the top if you're young and white. This is the top of the gay pyramid. No, like, those are the top ... the top of the pyramid. [...] Because they are so oppressed [sarcastic], because they are white, and males, and gay that ... you know? They go to the Village and people ... black people ... someone is always below them, you know? They have to be mean. They have to give their opinion about these black guys, about those Asian guys. They are more popular; they are more sought after. They have a lot of value in the Village, and they walk that way, and they treat me that way

[ ...]

Interviewer: But do you feel disconnected, in any way, from gay youth these days?

Russel: Yes.

Interviewer: Why do you feel disconnected?

Russel: Well, there's a point ... And it was Jacques who started talking to me - there's a point when in French the staff [of the bar] starts calling you "vous".

Interviewer: Ah ... Yes ... The polite way...

Russel: The polite " $t u$ " [in French].

Ahmed, one of the interviewees in Montreal, talks about club segmentation perceived during his visits to the Village. He mentioned that he prefers a club that charges an entrance fee and therefore is less busy. As a relatively young Muslim and not completely openly gay, Ahmed has reasons to avoid the Village, since his presence in gay clubs and bars may put his identity at risk of being discovered. So his presence in the Village boils down to drinking with friends in a bar (which, according to him, can be used as an excuse to be at the place - "I was just there with my friends") or attending the club he mentioned to be his favorite, which targets a younger audience and is not so busy. Its ethnic (Arabic) intersection does not preclude him from attending such places, and Ahmed did not cite racial prejudice throughout his interview nevertheless, the fear that other Arab people would acknowledge him and "denounce" his sexuality to religious or ethnic peers is a process of exclusion.

\section{Restrictive offer and the risk of stigmatization}

Brice reports a similar feeling to Ahmed's, although more extreme, regarding a place that has a much stricter benefit: a gay sauna. As a non-openly gay and while still married, Brice restricted his incursions into gay places to visit saunas. The benefits of the service offered, extremely limited, are clear in his narrative. Benjamin reinforces Brice's position, mentioning how the offer of bars is controlled by heterosexual business people, purely interested in profit:

Brice: You're not going there to socialize. You go there for a reason, you know? And you can handle those almost transparent sheets, and those torn towels, you know? And ... And ... um ... the horrible layout of the place, why ... you need a sexual and physical release. And it's ... well, fast and efficient. So yeah - I used to go before I separated and divorced [my ex-wife], and after, I mean ... The busiest time of these saunas is usually at three in the morning after the clubs have closed. If you have not found anyone to take home, you go to the sauna. And you find someone there.

Benjamin: Well, in some ways nothing has changed [the participant is about 80 years old] - there is a certain consistency in some environments - even the brands of drinks do not change. Now you have some silly cocktails, you know? Some good ... uh ... The decor ... It's uh ... It depends. My point is that gay bars tend to be cheap, dirty, and malicious. That's because they're not even owned by respected gay people - many of them are owned by straight people who want to exploit their gay clients without feeling anything but contempt for their customers. Um ... But ... As far as they make easy money and people come to drink they are satisfied. 
Lilian, a social organizer of a movement related to sexuality, reports how she organizes fundraising events and funds the actions of her movement. She explains that the movement needs money to fund its operation and regularly organizes parties. Lilian talks about what she calls a "radical accessibility audit:"

Interviewer: And what kinds of practices do you use to ensure that people will know that [the space of the parties organized by you] is open?

Lilian: [...] It's about, like, being responsible and transparent in the [place selection] process. [...] On the event pages, it's all about specifying, you know? Like, sometimes it's as simple as mentioning that we're in ... Um ... Indigenous territory [note: she uses the specific first-nation - Mohawk]. That sort of thing, you know?

[...]

Lilian: Or, like, it's important to warn you that it is unceded land, and it's not our territory... There it is ... Even if it's not, like - it's a party, after all. It's a Club. At least acknowledging that it is unceded territory is important - I think, like, doing ... For example, the last party we organized we did, like, a radical accessibility audit - which is something they do in another project - another group started, and that means, like, measure - take measures of space [actively], and really specify how accessible the space is, then ... To say that space is accessible is one thing, but to show that you are actively working and trying to open space for these people actually telling them [emphasis] how accessible space is, it's important. I think I get diversity in the group of DJs, like, get DJs that are not all the same, or the same people at every party - get new people ... Um ... So ... I ... I think, yeah, so I think it's about being transparent and showing the thought process, and how you are approaching [the organization of these] events. So, like, to mention what's going on, what's going on while you're thinking about it.

Thus, while Brice and Ahmed are at risk of stigma because they belong to minority categories (Brice by age, Ahmed by ethnicity), Lilian seeks to act on such a risk by promoting a specific action to ensure accessibility. Strict supply, in the case of Brice, Benjamin, and Ahmed, creates a constant need to resign to something that is perceived as negative. In Brice's case, resigning to the poor service offered in the saunas. For Benjamin, he is resigning to the "straight owners" who exploit their gay clients. In the case of Ahmed, the risk of being caught in an environment that puts him in a category stigmatized among Muslims. Lilian, however, acts concretely to avoid such perception in the people who attend the parties organized by her movement.

\section{How does exclusion operate in Montreal}

In general, Montreal presented an environment of homonormativity (HUNT and ZACHARIAS, 2008), with standard constructions and expansion of benefits. This standard made the city a palatable destination for tourists, but resulted in the exclusion of gay consumers who feel as they are part of "a zoo." Even if specific places offer narrower benefits - as in the case mentioned by Brice - some intersections are still restricted (such as an undisclosed gay man in a sauna or bar can present him a risk of being "discovered" and "betrayed"). However, the benefits of socializing in bars, in the case of Benjamin works as a source of criticism toward the exploitation of gay money by the straight owner. Such context has generated exclusions from the offers point of view, which have affected how participants understood, experienced, and practiced consumption. Exclusion operates in Montreal through three mechanisms: a) the creation of an attraction; b) the creation of segmented places; and c) the offer that has risks for some intersections.

\section{Intersectional exclusion in Porto Alegre}

In Porto Alegre the diffuse characteristic of gay marketplaces (see Figure 1) offers a higher risk to consumers - there is no regulation at any level (municipal, state or national) for the creation of gay districts. Such a risk is concentrated in the interviewees' narratives regarding their concerns about physical and psychological safety when circulating in the city's night scene. The neighborhood, known as a stronghold or gay place (Cidade Baixa) is therefore known in an emic fashion by the 
participants, but there is no specific policy to establish it officially. The collection and structuring of gay places in the city started with Nuances, an organization that has worked for more than 25 years (BARROSO, 2007), who periodically launches compilations of gay places in the city and provides a map to disseminate them among its audience.

\section{Exclusion from exclusivity}

Given the context of diffuse marketplaces, Porto Alegre presents its homonormativity (HUNT and ZACHARIAS, 2008) differently in comparison to Montreal: the normativity occurs in specific places and not in tourist destinations in a broader way. One of the interviewees who is not part of many minority intersections (Ricardo is a young man, white, post-degree student, and has a high discretionary income) gives an example of a place of exclusion:

Ricardo: It is that the 'economic gay' [the interviewee uses the 'economic' category meaning "the gay person that participates in the economic activity," or that of high purchasing power], that of Nova Olaria, was the Jetsetter of Porto Alegre. The guy from Bela Vista, who travels to Europe, the guy who's there - The guy who found a space with an super nice coffee, beautiful, a Guion, an alternative thing, like Paris and such - supercult... And then it started to be attended by those stigmatized guys, emos, black hair, etc... He did not like that, it is not part of his profile, the gay identity he has, and then he leaves.

Ricardo's narrative about the exclusion due to minority intersections in a space open to the public, continues in a more elucidative way (based on his privileged position) when talking about Posto 8, at Ipanema beach, in Rio de Janeiro. The selection of this excerpt, while escaping from the immediate field research, helps to understand how the expanded offer in places becomes excludable, from the point of view of the intersections:

Ricardo: I was telling you exactly this, diversity: you accept this guy there, who is gay, from the periphery - will you accept him in your space with you? No. Maybe these international gays who are there in Posto 8, back in Ipanema, if the "tigrada" [slang for low income people from peripheral neighborhoods], the "favelado" [person living in the favelas], starts to show up, he will not feel at ease - why does he feel at home there? Literally, from those years I lived in Rio, the first two, I ... practically lived in that place there.

Interviewer: In Posto 8?

Ricardo: Yes. Because then I was in this thing, in this dazzle, to meet, to meet foreign guys, to see who ... how it is to relate to someone - I was with a Russian guy, with a Czech guy, I'd been with an American, an Italian.

The lack of public policies that establish spaces of tourist destinations in Porto Alegre does not apply to the above excerpt. However, such a difference shows how a space established as a tourist attraction for affluent gay men who travel to consume in a tourist space (such as Posto 8), is formed in an emic fashion. In Ricardo's narrative, the space with a comprehensive offering of tourist attractions makes it a place where affluent gays will not feel comfortable.

\section{Strict benefits as possible escapism}

On the other hand, the diffusion of gay consumption places in Porto Alegre allows a more direct offer in some establishments, with a more limited benefit. Roberto, a black and low-income young person, reports the freedom he felt when he visited one of the bars in the northern region of Porto Alegre. The region is known as a more sexual-oriented space. Several of the areas of the north of the city offer 'dark rooms,' and an establishment next to the largest gay sauna in the city is well-known by the interviewees as a bar of the working class (in the words of Ricardo, bar of "pedreiros" [bricklayers]).

Roberto chose, as the first place to visit, the establishment known as the bar of the working class. At the same time, the bars mentioned in his interview are mostly those from the northern part of the city, with a restricted concentration of offers and benefits (focused on sexuality). Similarly, Rebecca mentioned the same place in her interview. As a crossdresser, she complains of the decrease in the number of spaces that receive her intersection. First, she mentions her age ("I am old") to explain why she stopped enjoying the nightlife. Then, the lack of specific spaces was mentioned again. 
Rebecca: Yeah, but there is no specific place - just parties... [...] But specific nightclubs, which I find interesting for those who work with shows, there are no more. As in Sao Paulo: São Paulo has [several] nightclubs, a drag goes here, or a drag goes there, or a crossdresser who performs in a show, goes to such a place, performs there, finishes the show - if there is time, she goes [to another] - I did this a lot in Porto Alegre when we had several clubs [...] but there are no more - clubs like that. Only specific parties.

In his evaluation about the public that go to the places, Roberto makes a comparison between places with stricter benefits and evaluates the participation of people who, because they are hiding their sexuality, restrict their consumption of gay places to saunas:

Roberto: But I do not know to tell you what public... Because it's actually the same public who goes to the parties. And there are several married guys, like, in the closet, and such... who go there for pleasure.

Interviewer: Do you think this happens more in the sauna?

Roberto: Much more. There's more there than in parties. Because there is less exposure.

Interviewer: Less exposure than in the sauna?

Roberto: Yes, less in the sauna than in the party, for sure.

Interviewer: How interesting.

Roberto: So, wow, there are many guys in the closet - He goes there just to have sex and leave, and that's it. Especially in the week. And l've never been there in the week. But everyone told me - that most of the guys are married guys, who leave work and go straight there [laughs].

Gil, a young, black man born in the Northeast of Brazil - recently relocated to Porto Alegre to work for the government - said that he only uses the virtual places (dating applications). His interview revealed an evaluation of the state of Rio Grande do Sul, which he considers more "macho and homophobic" than his home state. Gil revealed that moving to the city and the experiences he went through in this process, resulted in changes in the way he observed his race:

Gil: No, before... I ... I ... Before I came here [Rio Grande do Sul], in fact... my identity...

Interviewer: Excuse me, what's your identity?

Gil: My identity as black... My identity as black I only assimilated here.

Interviewer: Here in Porto Alegre?

Gil: No, here in the state. The first time someone referred to me as black was here, so I thought, "Am I black?" [Laughs]. Because then, back in the Northeast, black, is that person that is "blue" black [refers to blacks with darker skin tones].

Gil's moving to the Rio Grande do Sul and the hostility he felt are repeated throughout his narrative, and slowly the city of Porto Alegre and the state as a whole, unfold as a non-welcoming environment. Even with a more comfortable income position than Roberto, for example, Gil remains excluded from an environment by perceiving it negatively. Thus, Gil and Roberto corroborate the notion that, in both intersectional positions: a) the most open places to receive people in minority intersections are precisely the ones that offer more restricted benefits (bars in the north), and (b) even minority positions that enjoy higher discretionary income feel they are in hostile environments and do not consume in places with enhanced benefits.

Therefore, the exclusion in marketplaces considered open to diversity operates, in Porto Alegre, through a) offers based on exclusivity, and b) through extended benefits, which can be understood as hostile contexts - even for consumers with high discretionary income. Exclusion operates intersectionally, as some intersections will be considered a minority even if consumers are part of another intersection. 


\section{CONCLUSION}

Intersectionality has become a primary analytical tool for theorizing identity and oppression (NASH, 2008; HANKIVSKY and CORMIER, 2011). This article theorizes such identity concerns and exclusion processes and links them to the benefits offered in market environments.

The two cities researched presented, although based on different contexts, a framework of offers: on the one hand, homonormativity rooted in the specific and geographical concentration (Gay Village); on the other, normatized by market players (bars, saunas, and clubs). Saatcioglu and Corus (2016) classify the imbalance of relations between market players as a vulnerability. It is an imbalance that occurs when the individuals do not have control anymore. However, we add that such control may be intersectionally denied to some individuals - even if such individuals hold financial, cultural, or symbolic capital control, they will continue to be intersectionally deprived of consuming in some places (SAATCIOGLU and CORUS, 2016).

In the light of the concept of central-places (NAKAMURA, 2010) and difficulty of access for suburban or poor populations (WALKER, KEANE and BURKE, 2010), our contribution to the literature is to show that even for intersections with high cultural or economic capital (CASTILHOS and DOLBEC, 2017), the access restriction remains. Such an impediment occurs in places with a wide range of benefits, in which consumers seek benefits more homogeneously (tourist destinations, places for nightlife entertainment and socialization). In places with more limited benefits (such as saunas, book shops, cafes), such intersecting impediments are less apparent. For example, for some participants, high income does not solve the problem of feeling excluded in hostile environments (Gil and Saul). However, places offering more limited benefits (saunas, online applications) also offered less sense of exclusion. The study also adds to the conclusions of Gopaldas and Siebert (2018), showing that in addition to the exclusion related to two or more intersections (expected in the media, as per the authors), offers in the specific marketplaces is also excluding, even if the producers are clearly and ostensibly open to diversity.

Therefore, exclusion operated on an intersectional basis (CRENSHAW, 1989; COLLINS, 1990), respecting the benefits offered in gay places. In places with an increased benefit (for instance, the Gay Village as a tourist, gastronomic, and socialization attraction), there was more exclusion than in restricted benefit venues (saunas, online applications, less segmented bars).

Two initiatives drew attention during the field work, and are presented as proposals with managerial implications: a) the adoption of third parties to soften the intersectional exclusion; and b) the radical accessibility audit.

The first implication is adapted to the context of Porto Alegre. A nonprofit offers training and provides certification for marketplaces, issuing a certificate of LGBT accessibility for bars, restaurants, cafes, nightclubs and any other establishment that undergoes the organization's voluntary training. This intervening player in the market context softens the process of intersectional exclusion by visually highlighting the spaces that have submitted to training and specialization to receive the most diverse intersections that cross the LGBT categories. It is possible to conclude that the increasing number of actors involved in the process of certification and training in marketplaces can intersectionally reduce the feeling of exclusion in minority groups.

The second implication is described by Lilian: the active auditing of accessibility, with the availability of clear technical report about the communications of events (LGBT or others). Lilian warned of the need to put in numbers how accessible the space is - width of corridors, size of bathroom cabins, angle of access ramps, public capacity, door opening direction, height of steps, height of service desks, average decibels expected for the party or event, availability of non-alcoholic beverages, schedules of public and private transportation, training and safety specialization regarding racial sensitivity (to avoid situations of institutional racism) and gender sensitivity. These two managerial implications can reduce the problem of intersectional exclusion in spaces with a wide range of benefits.

As for the limitation of the study, the choice of identity (gay, instead of the broad LGBT category) leads to a reduced focus on male cisgender, which may hinder the understanding of other identity invisibilities in the field. 
For future research, we suggest studying in depth how intersectional exclusion occurs when the approach expands the number of identity groups. Also, it is interesting to deeply research the transcultural aspect of the study, since the analysis of the urban geographies of this work did not contemplate the aspect of cultural differences. It is recognized that cultural differences influence the observed market relations, but were not contemplated in this analysis. Also, the limitation mentioned before can also be considered as an opportunity for new research: the inclusion of other invisible identity categories (trans women and trans men, lesbians, bisexual people) may be an important way to expand the knowledge on intersectional exclusion in marketplaces. 


\section{REFERENCES}

ACKER, J. Inequality regimes gender, class, and race in organizations. Gender \& Society, v. 20, n. 4, p. 441-464, 2006.

AGIER, I.; SZAFARZ, A. Microfinance and gender: is there a glass ceiling on loan size? World Development, v. 42, p. 165-181, 2013.

BAKER, S. M.; GENTRY, J. W.; RITTENBURG, T. L. Building understanding of the domain of consumer vulnerability. Journal of Macromarketing, v. 25, n. 2, p. 128-139, 2005.

BARROSO, F. L. A. Jornal do Nuances: a prática midiática de uma ONG de Porto Alegre-RS para o confronto político entre o "gay classe média" e a" bicha bafona". São Leopoldo, RS, 2007.

BETTANY, S. et al. Moving beyond binary opposition: exploring the tapestry of gender in consumer research and marketing. Marketing Theory, v. 10, n. 1, p. 3-28, 2010.

BORGES, A. L. V.; SCHOR, N. Início da vida sexual na adolescência e relações de gênero: um estudo transversal em São Paulo, Brasil. Cadernos de Saúde Pública, v. 21, p. 499-507, 2005.

CARR, E. R. et al. Understanding the link between multiple oppressions and depression among African American women: the role of internalization. Psychology of Women Quarterly, v. 38, n. 2, p. 233-245, 2014.

CASTILHOS, R.; DOLBEC, P. Conceptualizing spatial types: characteristics, transitions, and research avenues. Marketing Theory,v. 18, n. 2, p. 154-168, 2017.

COLLINS, P. H. Black feminist thought: knowledge, consciousness, and the politics of empowerment. New York: Routledge, 1990.

COMMURI, S.; EKICI, A. An enlargement of the notion of consumer vulnerability. Journal of Macromarketing, v. 28, n. 2, p. 183-186, 2008.

CRENSHAW, K. Demarginalizing the intersection of race and sex: a black feminist critique of antidiscrimination doctrine, feminist theory and antiracist politics. The University of Chicago Legal Forum, v. 140 , p. $139-167,1989$.

CRENSHAW, K. Mapping the margins: intersectionality, identity politics, and violence against women of color. Stanford Law Review, v. 43 , n. 6, p. 1241-1299, 1991.

CROCKETT, D.; GRIER, S.; WILLIAMS, J. Coping with marketplace discrimination: an exploration of the experiences of black men. American Marketing Science Review, v. 2003, n. 4, p. 1-18, 2003.

CROCKETT, D.; WALLENDORF, M. Sociological perspectives on imposed school dress codes: consumption as attempted suppression of class and group symbolism. Journal of Macromarketing, v. 18, n. 2, p. $115-131,1998$.

DELOZIER, M.; RODRIGUE, J. Marketing to the homosexual (gay) market. Journal of Homosexuality, v. 31, n. 1-2, p. 203-212, 1996.

DENISSEN, A.; SAGUY, A. Gendered homophobia and the contradictions of workplace discrimination for women in the building trades. Gender \& Society, v. 28, n. 3, p. 381-403, 2014.

DION, D.; BORRAZ, S. Managing status: how luxury brands shape class subjectivities in the service encounter. Journal of Marketing, v. 81, n. 5, p. $67-85,2017$.
GOPALDAS, A. Intersectionality 101. Journal of Public Policy \& Marketing, v. 32, p. 90-94, 2013. Special issue.

GOPALDAS, A.; DEROY, G. An intersectional approach to diversity. Consumption, Markets \& Culture, v. 18, n. 4, p. 333-364, 2015.

GOPALDAS, A.; SIEBERT, A. Women over 40, foreigners of color, and other missing persons in globalizing mediascapes: understanding marketing images as mirrors of intersectionality. Consumption, Markets \& Culture, v. 21, n. 4, p. 323-346, 2018.

GURRIERI, L.; PREVITE, J.; BRACE-GOVAN, J. Women's bodies as sites of control: inadvertent stigma and exclusion in social marketing. Journal of Macromarketing, v. 33, n. 2, p. 128-143, 2013.

HANKIVSKY, O.; CORMIER, R. Intersectionality and public policy: some lessons from existing models. Political Research Quarterly, v. 64, n. 1, p. 217-229, 2011.

HUNT, M.; ZACHARIAS, J. Marketing the imaginary of Montréal's (gay) village. Canadian Journal of Urban Research, v. 17 n. 1, p. 28-57, 2008.

HUTTON, M. Consuming stress: exploring hidden dimensions of consumption-related strain at the intersection of gender and poverty. Journal of Marketing Management, v.31, n. 15, p. 1-23, 2015.

JAFARI, A.; GOULDING, C. We are not terrorists: UK based Iranians, consumption practices and the torn self. Consumption, Markets $\boldsymbol{\&}$ Culture, v. 11, n. 2, p. 73-91, 2008.

KATES, S. Out of the closet and out on the street! Gay men and their brand relationships. Psychology \& Marketing, v. 17, n. 6 , p. 493-513, 2000.

KATES, S. The protean quality of subcultural consumption: an ethnographic account of gay consumers. Journal of Consumer Research, n. 29, p. 383-399, 2002.

KHARE, A.; VARMAN, R. Kafkaesque institutions at the base of the pyramid. Journal of Marketing Management, v. 32, n. 17-18, p. 1619-1646, 2016.

KJELDGAARD, D.; CSABA, F.; GER, G. Grasping the global: multisited ethnographic market studies. In: BELK, R. (Orgs). Handbook of Qualitative Research Methods in Marketing.,Cheltenham, Edward Elgar Publishing, p. 521-533, 2006.

LANGLEY, P. Consuming credit. Consumption, Markets \& Culture, v. 17, n. 5, p. 417-428, 2014.

LEZNOFF, M. The homosexual in urban society. Montréal: McGill University, 1958.

LINDAU, S. et al. A study of sexuality and health among older adults in the United States. New England Journal of Medicine, v. 357, n. 8, p. 762-774, 2007.

LISBOA, T. Gênero, classe e etnia: trajetórias de vida de mulheres migrantes. Revista Katálysis, v. 6, n. 2, p. 251-252, 2003.

MARCUS, G. Ethnography in/of the world system: the emergence of multi-sited ethnography. Annual Review of Anthropology, v. 24, p. 95-117, 1995.

MCCRACKEN, G. The long interview. Newbury Park, CA: Sage, 1988. (Qualitative Research Methods Series n. 13). 
NAKAMURA, D. Spatial competition and consumer exclusion: social welfare perspectives in central-place system. Letters in Spatial and Resource Sciences, v. 3, p. 101-110, 2010.

NASH, J. Re-thinking Intersectionality. Feminist Review, n. 89, p. 1-15, 1995.

OLIVER, M. B.; HYDE, J. S. Gender differences in sexuality: a metaanalysis. Psychological Bulletin, v. 114, n. 1, p. 29-51, 1993.

PODMORE, J. Gone 'underground'? Lesbian visibility and the consolidation of queer space in Montréal, Social \& Cultural Geography, v. 7, n. 4, p. 595-625, 2006.

ROSEMBERG, F.; ANDRADE, L. F. Ação afirmativa no Ensino Superior brasileiro: a tensão entre raça/etnia e gênero. Cadernos Pagu, n. 31, p. 419-437, 2008.

SAATCIOGLU, B.; CORUS, C. Exploring spatial vulnerability: inequality and agency formulations in social space. Journal of Marketing Management, v. 32, n. 3-4, p. 230-251, 2016.
SAATCIOGLU, B.; OZANNE, J. A critical spatial approach to marketplace exclusion and inclusion. Journal of Public Policy \& Marketing, v. 32, p. 3232-3237, 2013.

SANGHVI, M.; HODGES, N. Marketing the female politician: an exploration of gender and appearance. Journal of Marketing Management, v. 31, n. 15-16, p. 1676-1694, 2015.

THOMPSON, C.; HAYTKO, D. Speaking of fashion: consumers' uses of fashion discourses and the appropriation of countervailing cultural meanings. Journal of Consumer Research, v. 24, n. 1 , p. 15-42, 1997.

WALKER, R.; KEANE, C.; BURKE, J. Disparities and access to healthy food in the United States: a review of food deserts literature. Health \& Place, v. 16, n. 5, p. 876-884, 2010.

WANG, J.; TIAN, Q. Consumer vulnerability and marketplace exclusion: a case of rural migrants and financial services in China, Journal of Macromarketing, v. 34 n. 1, p. 45-56, 2013.

Paulo Roberto Chaves Dalpian

ORCID: https://orcid.org/0000-0001-6714-586X

PhD in administration from the Federal University of Rio Grande do Sul (UFRGS). Professor at the Stamford International University, Bangkok, Thailand E-mail: paulo.dalpian@stamford.edu

PhD in administration from University of São Paulo (USP). Adjunct Professor at the School of Administration of the Federal University of Rio Grande do Sul-RS, Brazil. E-mail: tsilveira@ea.ufrgs.br 